\title{
Bacterial loading during flooding: a case study from 2010 on the Bi-national Rio Grande
}

\author{
A. Torres ${ }^{1}, \mathrm{~K}$. Tobin $^{1} \&$ B. Wilson ${ }^{2}$ \\ ${ }^{1}$ Centre for Earth and Environmental Studies, \\ Texas A\&M International University, USA \\ ${ }^{2}$ Department of Biology and Chemistry, \\ Texas A\&M International University, USA
}

\begin{abstract}
Escherichia coli (E. coli) bacteria loadings were tracked during the summer 2010 major flood event of the Rio Grande using the Soil and Water Assessment Tool (SWAT) hydrologic model. This bi-national watershed spanning Texas and Mexico has loading from urban point source sewage outfalls and non-point source loadings from rangeland and agricultural areas located upstream of a urban centre (Laredo/Nuevo Laredo). Flood events represent a high risk for human health since bacterial loadings increased during the flood. Sampling during flood conditions is dangerous and therefore there are comparatively few studies that have examined bacterial values in rivers during flood events. Therefore, the safest way to obtain bacterial concentrations during a flood event is through hydrologic modelling. Significantly, the initial assumption of constant bacterial loading within the basin is not valid. As demonstrated by previous research there is a strong linear correlation between streamflow and E. coli values. The outcomes of this study will provide guidelines for users of the SWAT model to predict bacteria fate and transport during future flood events and will therefore assist communities in improving management of their water supplies. Finally, use of satellite precipitation data as primary input for the SWAT model potentially extends the findings of this study to areas of the developing world that lack ground monitoring of precipitation.

Keywords: bacteria, SWAT, flood, sewage, Texas, Mexico, Rio Grande.
\end{abstract}




\section{Introduction}

This study utilized the SWAT model to simulate bacterial transport in the Rio Grande watershed during a July 2010 flood event. Study focuses on Escherichia coli (E. coli), a part of the group of faecal coliforms, present in the polluted Rio Grande. Analysis is based on comparison of major flood event data with more normal flow conditions that occurred before and after the flood. This study connects watershed hydrology with faecal bacteria statistical time series analysis to determine how the SWAT program can be utilized to facilitate future predictions of bacteria fate and transport within the Rio Grande.

\section{Study area}

This study examined segments of the Rio Grande both upstream and downstream of Laredo, Texas (United States) and Nuevo Laredo, Tamaulipas (Mexico, fig. 1). The upper segment begins at Columbia Bridge, which is located approximately $33 \mathrm{~km}$ north of Laredo. The basin outlet is located in the town of Rio Bravo, Texas, which is $26 \mathrm{~km}$ south of Laredo. The examined watershed is defined between the basin inlet and outlet and has an area of $2,589.375 \mathrm{~km}^{2}$.

The basin examined is divided into 26 subbasins by the SWAT model's Watershed Delineation Tool (fig. 1). The outlet of six subbasins along the Rio Grande corresponds with this study's field sampling sites, which are located in and downstream of Laredo and include Texas Commission of Environmental Quality (TCEQ) segments 20650 and 15816, table 1. This study's sites correspond with the water quality sampling locations of the Texas Clean River program operated by the TCEQ with local support from the City of Laredo Health Department. As with the TCEQ program water samples were collected on the US side of the river.

Table 1: $\quad$ TCEQ stations and SWAT model subbasins with sampling sites.

\begin{tabular}{|c|c|c|}
\hline $\begin{array}{c}\text { Sampling } \\
\text { Site }\end{array}$ & $\begin{array}{c}\text { TCEQ } \\
\text { Station }\end{array}$ & $\begin{array}{c}\text { SWAT } \\
\text { Subbasins }\end{array}$ \\
\hline 1 & 15816 & 26 \\
\hline 2 & 13196 & 25 \\
\hline 3 & 15815 & 22 \\
\hline 4 & 15814 & 19 \\
\hline 5 & 13202 & 18 \\
\hline 6 & 20650 & 14 \\
\hline
\end{tabular}

The primary sample site of this study was site 4, fig. 1, which corresponded with the location of the International Boundary and Water Commission (IBWC) streamflow gage (15814) and also was the outlet for subbasin 19. This site is adjacent to International Bridge II that connects the downtown areas of Laredo and Nuevo Laredo. Immediately upstream, within $1 \mathrm{~km}$, of site 4 there are 
significant $\left(10123 \mathrm{~m}^{3} / \mathrm{sec}\right)$ point source dischargers of raw sewage on the Mexican side of the river (Negrete [2]).

Three sample sites (sites 1-3; fig. 1) were examined downstream of Laredo. Site 1 is located near the water intake pipe for the town of Rio Bravo, Texas and where there is only ranch land present on the opposing Mexican side. Sites 1 and 2 are located 18 and $13 \mathrm{~km}$ downstream of site 4, respectively. Site 2 is within $2 \mathrm{~km}$ downstream of the Wastewater Treatment Plant for Nuevo Laredo.

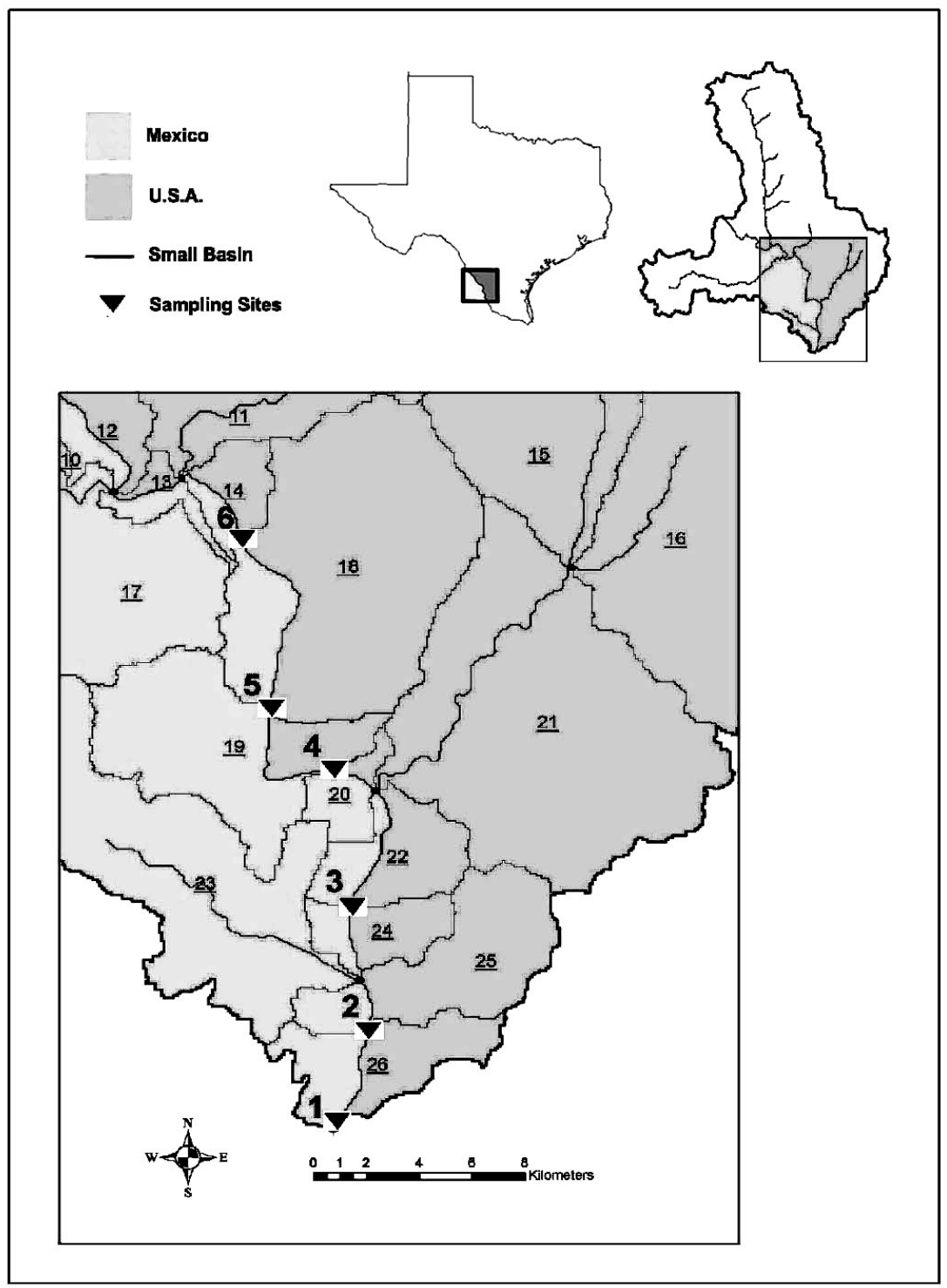

Figure 1: Study watershed. Sampling sites 1-6 within the basin. 
South Laredo Wastewater Treatment Plant. No significant inflows from Mexico are present across from site 3 .

Upstream of the primary site there are two sampling locations (sites 5-6; fig. 1). Site 5 is located at the Jefferson Water Treatment Plant (drinking water) in Laredo and is $6 \mathrm{~km}$ upstream from site 4 . Note that there is a major bend in the Rio Grande present between sites 4 and 5. Some turbulent back eddies were noted at site 5 . Site 6 is $14 \mathrm{~km}$ upstream of site 4 and is located close to the inlet of Manadas Creek; a location noted for heavy metal pollution. Significant riparian areas are noted along both the US and Mexican side of the Rio Grande studied.

The Rio Grande in Texas was regulated upstream of Laredo with the completion of Amistad Dam $300 \mathrm{~km}$ north of Laredo, which was finished in November 1969. A large quantity of water was released at Amistad Dam in early July 2010 that resulted in the inundation of cities along the Rio Grande downstream of the dam. At Laredo the river crested on July $8^{\text {th }}$ and $9^{\text {th }}(12.94 \mathrm{~m}$, $3170 \mathrm{~m}^{3} / \mathrm{sec}$ ). Since Amistad Dam was constructed the 2010 flood was second greatest in magnitude with slightly greater flow recorded in $1971\left(3260 \mathrm{~m}^{3} / \mathrm{sec}\right)$.

\section{Methods}

This study examined both observed and simulated bacterial concentrations in the Rio Grande. Observed bacterial values were obtained through the MF method (US EPA Method 1603 [3]) that provided a direct count of E. coli in water based on the development of colonies that grew on the surface of a membrane filter.

Simulated bacterial concentrations were determined using the SWAT model. Tobin and Bennett [1] previously modeled the middle Rio Grande Basin, which overlaps with the study area, and this work provided information that facilitated model calibration. The precipitation dataset input into the model was the National Weather Service Multisensor Estimator product (MPE). The model was run from January 1, 2009 to September 30, 2010 covering the July 2010 flood period. The first eight months of the run was used as an initialization period to warm-up the model.

SWAT model results were validated with two metrics, the Nash-Sutcliffe model efficiency coefficient (NS) and the Mass Balance Error (MBE). The Nash-Sutcliffe model efficiency coefficient (NS) was used to evaluate the predictive power of hydrological models.

$$
\mathrm{NS}=1-\frac{\sum_{\mathrm{t}=1}^{\mathrm{T}}\left(\mathrm{Q}_{\mathrm{o}}^{\mathrm{t}}-\mathrm{Q}_{\mathrm{s}}^{\mathrm{t}}\right)^{2}}{\sum_{\mathrm{t}=1}^{\mathrm{T}}\left(\mathrm{Q}_{\mathrm{o}}^{\mathrm{t}}-\mathrm{Q}_{\mathrm{a}}^{\mathrm{t}}\right)^{2}}
$$

where $\mathrm{Q}_{0}^{\mathrm{t}}$ is the observed bacteria value, $\mathrm{Q}_{\mathrm{s}}^{\mathrm{t}}$ is the simulated streamflow (bacteria) value, and $\mathrm{Q}_{\mathrm{a}}^{\mathrm{t}}$ is the average observed bacteria value (Nash and Sutcliffe [4]). The Mass Balance Error (MBE) directly compared the totals of simulated and observed bacteria and is defined below.

$$
\mathrm{MBE}=\frac{\sum_{\mathrm{t}=1}^{\mathrm{T}}\left(\mathrm{Q}_{\mathrm{s}}^{\mathrm{t}}-\mathrm{Q}_{\mathrm{o}}^{\mathrm{t}}\right)}{\sum_{\mathrm{t}=1}^{\mathrm{T}} \mathrm{Q}_{\mathrm{o}}^{\mathrm{t}}}
$$


Table 2 describes the model performance metrics as suggested by Moriasi et al. [5]. If the NS number is between 0.75 and 1.00 , or the percent MBE is within $\pm 15 \%$, then the model performance is very good. NS between 0.65 and 0.75 is considered as a good model as well as a percent MBE between $\pm 15 \%$ and $\pm 30 \%$. When the NS value falls between 0.50 and 0.65 (or MBE between $\pm 30 \%$ and $\pm 55 \%$ ), the model performance is considered satisfactory. Any NS result lower than 0.50 or any MBE percent higher than $\pm 55 \%$ is considered as an unsatisfactory model performance, where it is recommended to either re-evaluate the parameters used in model, or to discard it completely.

Table 2: $\quad$ Model performance metrics (modified from Moriasi et al. [5]).

\begin{tabular}{|c|c|c|}
\hline $\begin{array}{c}\text { Performance } \\
\text { Rating }\end{array}$ & NS & MBE \\
\hline Very Good & $0.75<\mathrm{NS} \leq 1.00$ & $\mathrm{MBE}< \pm 15 \%$ \\
\hline Good & $0.65<\mathrm{NS} \leq 0.75$ & $\pm 15 \% \leq \mathrm{MBE}< \pm 30 \%$ \\
\hline Satisfactory & $0.50<\mathrm{NS} \leq 0.65$ & $\pm 30 \% \leq \mathrm{MBE}< \pm 55 \%$ \\
\hline Unsatisfactory & $\mathrm{NS} \leq 0.50$ & $\mathrm{MBE} \geq \pm 55 \%$ \\
\hline
\end{tabular}

At the Columbia Bridge inlet persistent bacterial loadings were either assumed to be a constant value $(125,1,250,12,500$ Colony Forming Units or $\mathrm{CFU} / 100 \mathrm{ml}$ ) or a variable value based upon the linear regression of streamflow versus observed persistent bacteria values at the closest sampling site (\#6) to Columbia Bridge.

Effluent from wastewater treatment plants was present in several of the subbasins that define the examined watershed (fig. 1). Persistent bacterial loading was assumed to be $200 \mathrm{CFU} / 100 \mathrm{ml}$, which is the legal upper limit for treated wastewater (NTAC [6]; US EPA [7]). Immediately upstream of site 4, within subbasin 19, fifteen conduits on the Mexican side of the river acted as point dischargers for raw sewage. The nominal value for loading of raw sewage is $10,122.9 \mathrm{~m}^{3} /$ day. Additionally, during the July 2010 flood event the City of Laredo documented the release of domestic sewer water localized at the International Bridge II lift station (near site 4) of approximately $30,000 \mathrm{~m}^{3} /$ day.

A total of thirteen SWAT simulations were conducted to account for different possible loadings. Simulations 1 to 4 had bacterial loading at the basin inlet, wastewater treatment plants, and raw sewage dischargers from subbasin 19. Raw sewage had an assumed concentration of persistent bacteria at $10^{6} \mathrm{CFU} / 100 \mathrm{ml}$, which is the median value for this type of effluent (Sturman et al. [8]). Simulations 1 to 3 were based on a constant persistent bacterial loading (125, $1,250,12,500 \mathrm{CFU} / 100 \mathrm{ml}$ ). Bacterial loading in simulation 4 was based on a variable value from regression analysis as described above. Simulations 5 to 8 were similar to the above four simulations except without bacterial loading added within subbasin 19. Simulations 9 and 10 were similar to simulation 4 except that the assumed concentration of persistent bacteria was $10^{7}$ and $10^{8}$ CFU/ $100 \mathrm{ml}$, respectively. Simulations 11 to 13 account for a worst-case scenario where releases of sewage during the second week of the July 2010 flood 
were assumed to be thirteen times higher than was reported again with assumed persistent bacterial concentrations of $10^{6}, 10^{7}$ and $10^{8} \mathrm{CFU} / 100 \mathrm{ml}$.

\section{Results}

Both observed and simulated bacteria data were measured as CFU and were examined from sites 1, 4, 5, and 6, fig. 1. On July 9 and 23 flood conditions made sites 1 and 6 inaccessible. Relatively high values (generally in the thousands of CFU) were recorded before the main flood event (May-June, 2010), which was a time with above average streamflow and with periods of minor flooding (flow in the range of 100 to $300 \mathrm{~m}^{3} / \mathrm{sec}$ ). During the flood crest (July 9) extremely high $E$. coli values (in the tens of thousands of CFU) were noted at all examined sites. After the flood crest, in mid-July to late August, E. coli the values were much lower, generally $<1,000 \mathrm{CFU}$, at all sites.

Simulated persistent bacterial values were determined based on several different assumptions about the nature of point source loading in the river. The most fundamental modelling assumption made was the bacterial loading value at the basin inlet. The initial assumption was that bacterial loading was constant and did not change with streamflow (simulations 1,2, and 3) and this assumption produced unacceptable simulations, based on MSE and NS values, table 3 . Conversely, simulation 4 was based on variable bacterial loading at the basin inlet as described in the methodology section. This simulation yielded acceptable MSE and NS values at all sites, table 3, and closely corresponds with the observed average E. coli value, fig. 2 .

Table 3: $\quad$ Simulated persistent bacterial values (CFU).

\begin{tabular}{|c|r|r|r|r|r|r|r|r|}
\hline & \multicolumn{1}{|c|}{ Site 1 } & & \multicolumn{1}{c|}{ Site 4 } & & \multicolumn{1}{c|}{ Site 5 } & & \multicolumn{1}{c|}{ Site 6 } & \\
\hline & MBE & \multicolumn{1}{c|}{ NS } & \multicolumn{1}{c|}{ MBE } & \multicolumn{1}{c|}{ NS } & \multicolumn{1}{c|}{ MBE } & \multicolumn{1}{c|}{ NS } & \multicolumn{1}{c|}{ MBE } & \multicolumn{1}{c|}{ NS } \\
\hline 1 & $-28 \%$ & -0.07 & $-80 \%$ & -0.30 & $-92 \%$ & -0.26 & $-95 \%$ & -0.24 \\
\hline 2 & $71 \%$ & -0.65 & $6 \%$ & -0.17 & $-21 \%$ & -0.02 & $7 \%$ & -0.06 \\
\hline 3 & $1100 \%$ & -167 & $220 \%$ & -1.95 & $695 \%$ & -12.41 & $435 \%$ & -5.13 \\
\hline 4 & $\mathbf{- 5 \%}$ & $\mathbf{0 . 5 5}$ & $-\mathbf{4 1 \%}$ & $\mathbf{0 . 7 4}$ & $\mathbf{1 9 \%}$ & $\mathbf{0 . 8 3}$ & $\mathbf{- 8 \%}$ & $\mathbf{0 . 9 7}$ \\
\hline 5 & $-88 \%$ & -1.08 & $-97 \%$ & -0.37 & $-92 \%$ & -0.26 & $-95 \%$ & -0.24 \\
\hline 6 & $14 \%$ & -0.03 & $-70 \%$ & -0.19 & $-21 \%$ & -0.02 & $-47 \%$ & -0.06 \\
\hline 7 & $1040 \%$ & -149 & $204 \%$ & -1.64 & $695 \%$ & -12.41 & $435 \%$ & -5.13 \\
\hline 8 & $-66 \%$ & -0.06 & $-58 \%$ & 0.69 & $\mathbf{1 9 \%}$ & $\mathbf{0 . 8 3}$ & $\mathbf{- 8 \%}$ & $\mathbf{0 . 9 7}$ \\
\hline 9 & $542 \%$ & -54.4 & $107 \%$ & -0.13 & $\mathbf{1 9 \%}$ & $\mathbf{0 . 8 3}$ & $\mathbf{- 8 \%}$ & $\mathbf{0 . 9 7}$ \\
\hline 10 & $6017 \%$ & -6576 & $1593 \%$ & -139 & $\mathbf{1 9 \%}$ & $\mathbf{0 . 8 3}$ & $\mathbf{- 8 \%}$ & $\mathbf{0 . 9 7}$ \\
\hline 11 & $31 \%$ & -0.78 & $-\mathbf{2 8 \%}$ & $\mathbf{0 . 8 0}$ & $\mathbf{1 9 \%}$ & $\mathbf{0 . 8 3}$ & $\mathbf{- 8 \%}$ & $\mathbf{0 . 9 7}$ \\
\hline 12 & $903 \%$ & -210 & $239 \%$ & -3.02 & $\mathbf{1 9 \%}$ & $\mathbf{0 . 8 3}$ & $\mathbf{- 8 \%}$ & $\mathbf{0 . 9 7}$ \\
\hline 13 & $9623 \%$ & -22372 & $2909 \%$ & -518 & $\mathbf{1 9 \%}$ & $\mathbf{0 . 8 3}$ & $\mathbf{- 8 \%}$ & $\mathbf{0 . 9 7}$ \\
\hline
\end{tabular}

Numbers in bold indicate acceptable simulations. 


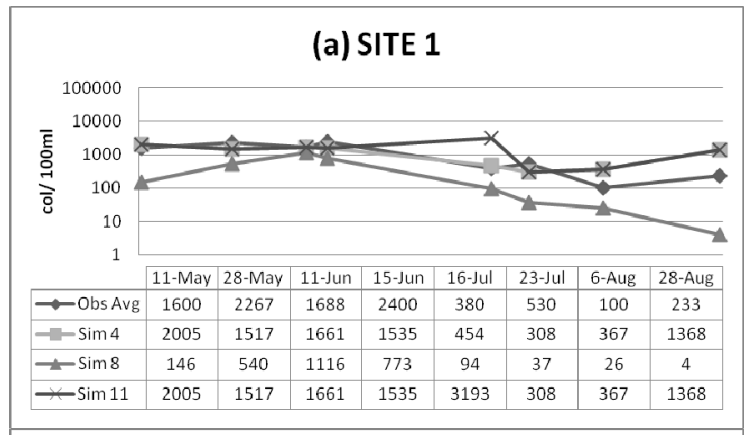

(b) SITE 4

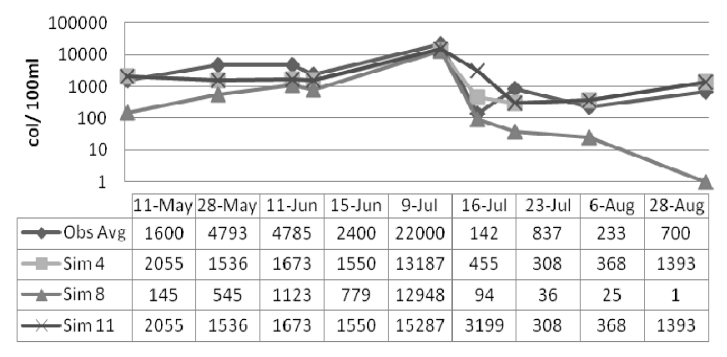

\section{(c) SITE 5}

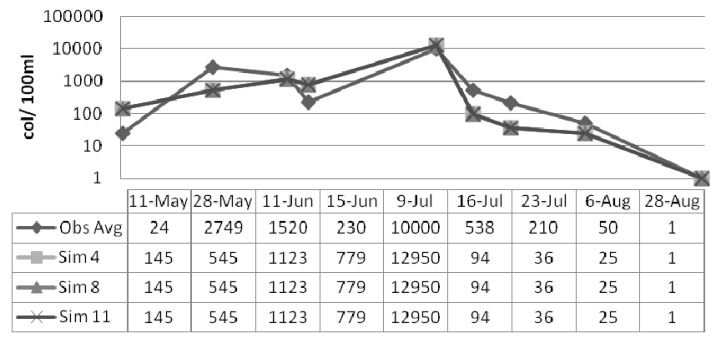

(d) SITE 6

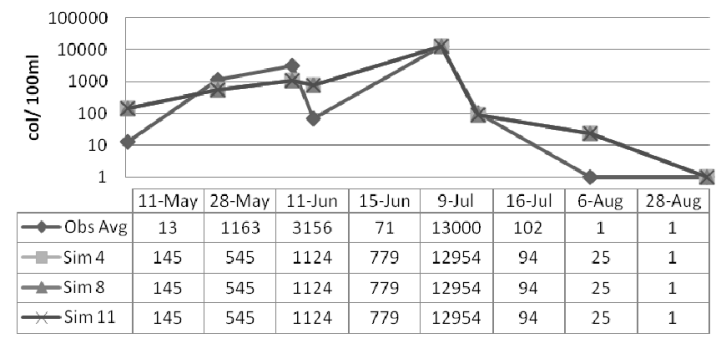

Figure 2: $\quad$ E. coli CFU - (a) Site 1, (b) Site 4, (c) Site 5, and (d) Site 6. 
Simulations 5 to 8 were identical to model runs 1 to 4 except that sewage was not input into subbasin 19 to test the impact that sewage had on the bacterial loading at sites 1 and 4. Not surprisingly, table 3 and fig. 2 show that these simulations had an unacceptable negative bias.

In simulation 4 the median value for CFU in the sewage effluent emitted in subbasin 19 was assumed to be $10^{6} \mathrm{CFU} / 100 \mathrm{ml}$. To test the sensitivity of the assumed CFU value simulations 9 and 10 were ran with values of $10^{7}$ and $10^{8}$ CFU/ $100 \mathrm{ml}$, respectively. Table 3 shows the extreme positive bias in these simulations validating our initially assumed CFU value of $10^{6} \mathrm{CFU} / 100 \mathrm{ml}$.

During the period of July 9 to 16 the City of Laredo reported releases of untreated wastewater. Simulations 11 to 13 document a worse-case scenario where releases were assumed to be over an order of magnitude higher than was reported. At sites 1 and 4 simulation 11 yielded acceptable MBE and NS values, table 3, which were comparable to both simulation 4 and observed bacterial loading, fig. 3. However at site 1, simulation 11 had an unacceptable NS value indicating that the reported sewage releases were accurate.

\section{Discussion}

The fundamental question addressed in this paper is whether $E$. coli values can exceed regulatory guidelines during high flow conditions. Results demonstrate that $E$. coli values were underestimated during flood conditions, since the bacterial loading from runoff and floodplain inundation were not taken under consideration; therefore, $E$. coli values exceeded regulatory guidelines during high flow conditions. This study confirmed that bacterial loading could be simulated by the SWAT model potentially informing management decisions associated with extreme weather/flow conditions.

Davies-Colley et al. [9] and McKergow and Davis-Colley [10] documented a strong linear correlation between bacterial values and streamflow from small to moderated size watersheds from New Zealand. Our study initially assumed that bacterial loading at the basin inlet was constant; this assumption was the basis for SWAT simulations 1 to 3 . Table 3 illustrates the assumption of constant bacterial loading is not valid. To fix this problem, we adopted the approach of Davies-Colley et al. [9] by generating variable bacterial loading at the basin inlet, which produced acceptable results (simulation 4; table 3).

Within the examined watershed there were both point and non-point sources for bacterial loading. The most significant permanent point source of bacterial loading along the river was associated with sewage outfalls present in Nuevo Laredo. Transient loading sources present during the July 2010 flood included point sources dischargers of untreated raw sewage from Laredo (Archer [11]) and non-point sources including contributions from overland runoff and flooding of the riparian zone adjacent to the river (Ferguson [12]). Sturman et al. [8] indicated that combined sewer overflows have Total Coliforms $10^{5}-10^{7} \mathrm{MPN} / 100 \mathrm{ml}$. Potential bacterial loading from overland runoff included urban, agricultural and rangeland areas. Runoff from urban sources had variable, 
but generally lower than sewage, values for bacteria (Sturman et al. [8]; Total Coliforms, $10^{1}-10^{8} \mathrm{MPN} / 100 \mathrm{ml}$ ).

During the river flood event, potential bacterial loading from overland runoff in the basin can occur from urban, agricultural, and rangeland areas. Additionally, inundation of floodplains can contribute to bacteria loading. Sites 2, 3, 5 and 6 were situated adjacent to floodplain areas; whereas, sites 1 and 4 were more dominated by urban runoff.

Rangeland areas generate large loads of $E$. coli and faecal bacteria concentrations. Cattle and their manure in soils are the dominant factor affecting the quantity of live bacteria within rangeland areas. Generally, E. coli concentrations in dry manure are $4 \times 10^{7} \mathrm{CFU} / \mathrm{g}$ (Crane and Moore [13]). Bacterial populations are subject to change with environmental factors, such as temperature, rainfall duration and intensity, and extent of inundated land. These factors may determine whether or not faecal bacteria are transported with overland runoff during a rain event or detached from soil particles during a land inundation event (Khaleel et al. [14]; Walker et al. [15]). Another consideration is the effect of the die-off rate of microorganisms within overland runoff, which is calculated using the first-order decay relationship expressed as Chick's Law (Moore et al. [16]). The same conditions are associated with the inundated riparian zone during flooding, where wildlife excrete faeces with faecal coliforms and $E$. coli that can be directly incorporated into runoff within the river.

To track bacterial loading sources several series of SWAT simulations were performed. Simulation 4 was the default simulation that includes point source loading from Nuevo Laredo with $E$. coli assumed to be CFU $10^{6} / 100 \mathrm{ml}$ and this simulation yielded acceptable results at all sites, table 3. A series of SWAT simulations (5-8) with inlet loading the same as simulations (1-4) but with no sewage point source loading were executed. At sites 1 and 4 , which are downstream of the sewage point source, simulation 8 consistently underestimated $E$. coli values, fig. 2. This result demonstrated that sewage dischargers from Nuevo Laredo contributed significantly to the bacterial loading of the river downstream of the city. Flint [17] has documented that Total Faecal Coliforms including E. coli bacteria can survive for prolonged periods in surface water bodies. Therefore, bacterial loading from point sources in subbasin 19 can be attributed to the excess loading noted at, and downstream, of TCEQ station 15814 (site 4).

Simulations 9 and 10 used elevated assumed $E$. coli values $\left(10^{7}\right.$ to $10^{8}$ $\mathrm{CFU} / 100 \mathrm{ml})$. Results from these simulations had extreme positive biases, table 3 , indicating that the assumed value of $10^{6} \mathrm{CFU} / 100 \mathrm{ml}$ was more realistic. The $10^{6} \mathrm{CFU} / 100 \mathrm{ml}$ assumed value is the median value for combined sewer outflows, which is similar to values reported by Sturman et al. [8]. Cho et al. [18] converted faecal bacteria concentrations from CFU estimates to MPN estimates and found that MPN and CFU estimates are comparable. Additionally, laboratory inspection of bacterial plates indicated that $E$. coli is the dominant type of coliforms in the examined samples. 
During the 2010 Rio Grande flood event the stream flow peaked at 3170 $\mathrm{m}^{3} / \mathrm{sec}$ and then receded rapidly within one week. From July $8^{\text {th }}$ to July $16^{\text {th }}$ high flow forced wastewater to spill from the Bridge II lift station (Laredo). Unfortunately, site 1 was not accessible during the flood event. Simulations 11 to 13 model the worst case scenario for this incident where the amount of sewage is assumed to be 13 times higher than the official numbers reported from the City of Laredo, which was plausible given the unknown amount of sewage released from Nuevo Laredo at this time. Again these simulations had assumed E.coli of $10^{6}$ to $10^{8} \mathrm{CFU} / 100 \mathrm{ml}$ with simulation $11,10^{6} \mathrm{CFU} / 100 \mathrm{ml}$, yielding best results, table 3. However, simulation 11 did not perform as well as the default simulation 4 indicating that sewage releases were not grossly over-reported.

The above SWAT modelling was based on the following assumption. The examined watershed was relatively small $\left(2,589.375 \mathrm{~km}^{2}\right)$ and the total length of the river from sites 1-6 was only $32 \mathrm{~km}$. Therefore, bacteria die-off and growth was not considered as a major factor, since $E$. coli bacteria loading at site 6 travels to site 1 without significant growth or death. This assumption was justified based on limited travel times of bacteria within the river; less than six hours under normal flow conditions and even less during the flood event. E.coli die-off rate in surface runoff is 0.659 day $^{-1}$, and E.coli die-off rate in stream water is $0.990 /$ day $^{-1}$ (Crane and Moore [13]).

Bacterial and nutrient dynamics during pre-flood, flood and post-flood conditions varied significantly. Bacterial contamination during the pre-flood time period was strongly influenced by known point source near Site 4 where there significant raw sewage outfalls. Sites 1 and 4 are considered contaminated by the TCEQ with typical E. coli values in excess $10^{3} \mathrm{CFU} / 100 \mathrm{ml}$ (Archer [11]). Conversely, sites 5 and 6 typically have $E$. coli concentrations less than the regulatory limit set by the TCEQ of $200 \mathrm{CFU} / 100 \mathrm{ml}$ and commonly can have very low values approaching zero (Archer [11]). However, the period of May and June 2010 had inordinately high rainfall. Consequently, bacterial loading from non-point sources urban, agricultural, and rangeland areas contributed to elevated $E$. coli values, table 3 , in even relatively clean sites $(5,6)$.

During peak flood conditions (July 9), the floodplain adjacent to the river was inundated, facilitating significant non-point source loading with greatly elevated $E$. coli values at all sites, which is consistent with previous research (DaviesColley et al. [9]; McKergow and Davis-Colley [10]). Bacterial mobilization from the flooded riparian zone likely served as a large source for E. coli, and nutrients, during this event.

Davies-Colley et al. [9]; McKergow and Davis-Colley [10] documented a sharp decrease in bacterial loading in rivers after a flood event. Results from this study are consistent with the above observation. McKergow and Davis-Colley [10] indicates that bacterial stores present in channel and adjacent floodplain sediments are rapidly washed downstream. E. coli values during the post-flood period are very low at sites 5 and $6\left(\leq 10^{2} \mathrm{CFU} / 100 \mathrm{ml}\right)$ indicative of the depleted state of bacteria in the river. Even at sites 1 and $4 E$. coli values are lower than average $\left(\leq 10^{3} \mathrm{CFU} / 100 \mathrm{ml}\right)$. 
This study has implications for understanding how bacterial loading varies between normal and high flow conditions. Environmental monitoring of rivers is generally conducted under normal flow conditions when it is safe to be in close proximity to the river. Therefore, existing records of $E$. coli from sources such as the TCEQ, are biased by the omission of high values associated with floods. This conclusion potentially has regulatory significance in that during floods even relatively clean river segments can have E. coli values that greatly exceed acceptable standards. The strong correlation between streamflow and E. coli can be utilized to predict bacterial loading during future floods without the risk of sampling during non-safe flow conditions. Finally, the SWAT model is capable of accepting many types of precipitation data to support modelling. Use of remotely sensed precipitation products such as from NASA's Tropical Rainfall Measurement Mission can potentially extend the approaches articulated in this study to the developing world where there is an acute need for water quality monitoring.

\section{Conclusions}

Even so called clean stream reaches can exceed regulatory limits with high $E$. coli values during flooding. This study provides guidelines for users of the SWAT model to predict bacteria fate and transport during future flood events and therefore can potentially assist communities in improving management of their water supplies during periods of hydrometeorological extremes.

\section{References}

[1] Tobin, K.J. and Bennett, M.E., Using SWAT to model streamflow in two river basins with ground and satellite precipitation data. Journal of American Water Resources Association, 45(1), pp. 253-271, 2009.

[2] Negrate, D., Personal communication, 22 January 2010, Director of Comision Internacional de Limites y Aguas, Nuevo Laredo, Mexico.

[3] Method 1603. Escherichia coli (E. coli) in water by membrane filtration using modified membrane - Thermotolerant Escherichia coli agar (modified mTEC). United States Environmental Protection Agency (USEPA). http://www.epa.gov/microbes/1603sp02.pdf

[4] Nash, J.E. and Sutcliffe, J.V., River flow forecasting through conceptual models part I - a discussion of principles. Journal of Hydrology, 10(3), pp. 282-290, 1970.

[5] Moriasi, D.N., Arnold, J.G., Van Liew, M.W., Bingner, R.L., Harmel, R.D. and Veith T.L., Model evaluation guidelines for systematic quantification of accuracy in watershed simulations. Transactions of the ASABE, 50(3), pp. 885-900, 2007.

[6] NTAC (National Technical Advisory Committee), http:/www.cdph.ca.gov//healthinfo/ environhealth/water/Documents/

Beaches/AppendixB.pdf. 
[7] USEPA (US EPA Guidance for Recreational Waters and Beaches), http://www.cdph.ca.gov/HealthInfo/environhealth/water/Documents/Beach es/APPENDIXB.pdf

[8] Sturman, J., Ho, G. and Mathew, K. Water Auditing and Water Conservation. IWA Publishing: London, 2004.

[9] Davies-Colley, R., Lydiard, E. and Nagels, J.W., Stormflow-dominated loads of faecal pollution from an intensively dairy-farmed catchment. Water Science and Technology, 57, pp. 1519-1523, 2008.

[10] McKergow, L.A. and Davies-Colley, R.J., Stormflow dynamics and loads of Escherichia coli in a large mixed land use catchment. Hydrologic Process, 24, pp. 276-289, 2010.

[11] Archer, J., Personal communication, 22 April 2011, Environmental Investigator III, Texas Commission on Environmental Quality, Laredo, US.

[12] Ferguson, L.C. Quantification of the Role of Large Woody Debris for Coho Habitat Restoration. Master's Thesis: University of California at Davis, 2005.

[13] Crane, S.R. and Moore, J.A., Modeling enteric bacterial die-off: a review. Water Air Soil Pollution, 27, pp. 411-439, 1986.

[14] Khaleel, R., Foster, G.R., Reddy, K.R., Overcash, M.R. and Westerman, R.W., A nonpoint source model for land areas receiving animal wastes: IV. A conceptual model for sediment and manure transport. Transactions of the $A S A B E$, 22(6), pp. 1353-1361, 1979.

[15] Walker, S.E., Mostaghimi, S., Dillaha, T.A. and Woeste, F.E., Modeling animal waste management practices: impacts on bacteria levels in runoff from agricultural lands. Transactions of the ASABE, 33(3), pp. 807-817, 1990.

[16] Moore, J.A., Smyth, J.D., Baker, E.S., Miner, J.R. and Moffitt, D.C. Modeling bacteria movement in livestock manure systems. Transactions of the ASABE, 32(3), pp. 1049-1053, 1989.

[17] Flint K.P., The long-term survival of Escherichia coli in river water. Journal of Applied Bacteriology, 63, pp. 261-270, 1987.

[18] Cho, K.H., Han, D., Park, Y., Lee, S.W., Cha, S.M., Kang, J.H. and Kim, J.H., Evaluation of the relationship between two different methods for enumeration fecal indicator bacteria: colony-forming unit and most probable number. Journal of Environmental Science (China), 22(6), pp. 846-850, 2010. 